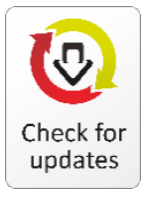

\section{IP EN}

\author{
AFFILIATION: \\ ${ }^{1}$ Manajemen Perpajakan, Fakultas \\ Ekonomi, Universitas Widya \\ Dharma Klaten. Jawa Tengah. \\ Indonesia \\ 2 Manajemen, Fakutas Ekonomi, \\ Universitas Islam Indonesia. \\ Yogyakarta. Indonesia.

\section{*CORRESPONDENCE:} \\ syskaladys@gmail.com
}

\section{THIS ARTICLE IS AVALILABLE IN}

http://journal.umy.ac.id/index.php/mb

DOI: $10.18196 / \mathrm{mb} .10178$

\section{CITATION:}

Sulistyowatie, S. L., \& Pahlevi, R. W. (2019). Innovation of Business and Environmental Performance in Kebon Indah Batik Association Klaten: The Impact of Transfer of Knowledge and Quality Management. Jurnal Manajemen Bisnis, 10(2), 192-203.

\section{INNOVATION OF BUSINESS AND ENVIRONMENTAL PERFORMANCE IN KEBON INDAH BATIK ASSOCIATION KLATEN: THE IMPACT OF TRANSFER OF KNOWLEDGE AND QUALITY MANAGEMENT}

\author{
Syska Lady Sulistyowatie ${ }^{1 *}$ and Reza Widhar Pahlevi ${ }^{2}$
}

\begin{abstract}
The creation of environmental performance is not only influenced by aspects of innovation but also the need for quality management to improve competitiveness and create competitive advantage. This research was conducted at the Kebon Indah Batik Association in Bayat, Klaten, Central Java. Kebon Village is one of the centers of written batik using natural dyes. At present, five batik groups have been formed, consisting of 169 members, including Sidoluhur, Nusa Indah, Nuju Makmur, Sido Makmur, and Tsp Mukti and this research is aimed at determining the effect of knowledge transfer and quality management on environmental performance through innovation. This study uses primary data sources namely all members of the Kebon Indah Batik Association in Bayat, Klaten, Central Java. The data collection at an early stage were collected through an independent questionnaire, to analyze the conditions of the organization mapping, especially relating to the transfer of knowledge, quality management of environmental performance through innovation. The data was analyzed by using SPSS Path Analysis model. The results of the study showed that knowledge transfer and quality management influence environmental performance and innovation. Innovation has an influence on environmental performance. Based on the results of the path analysis that there is an influence between knowledge transfer on environmental performance through innovation and there is an influence between quality management on environmental performance through innovation. Innovation bridges the role of knowledge transfer on environmental performance.
\end{abstract}

Keywords: Knowledge Transfer; Quality Management; Environmental Performance and Innovation.

\section{Introduction}

The global market competition currently, the role of society and government needs to pay more attention to the environmental and social impacts on companies in order to increase efficiency and reduce risks to humans and the environment (Alonso, Rubio, \& de Agustina 2017). In the 1990 s, issues began to emerge about the destruction of resources and the 
environment as a result of the rapid industry. The consumer demands for high quality products, low waiting times, intense business competition, increased technological capabilities, and decreased life cycle of the product requires companies to continue to innovate.

Innovation bridges the role of knowledge transfer to environmental performance. Knowledge is an important strategic resource for innovation activities (Xie, 2016) resulting from effective knowledge management and is considered as an important method for increasing the innovation capacity of a company (Donate, 2015). Based on innovation system theory, the transfer of knowledge is very important between parties involved in the innovation system. It means that the transfer and absorption of knowledge explicitly is an important aspect of innovation (When \& Montalvo, 2018).

If someone is willing to transfer the knowledge they have to others, it can affect collective learning and synergistic benefits, as well as develop creative and innovative ideas. Brachos, Kostopoulos, Soderquist, and Prastacos (2007) said that if employees are motivated to share knowledge with others, it will increase trust among them so that they contribute to increase innovation which is a key factor in achieving company success (Smith, Collins, \& Clark 2005). Creating good environmental performance is not only influenced by innovation aspects but also the need for quality management to improve competitiveness and create competitive advantage (Manders, 2012). Quality management can create an organizational environment to drive business innovation. However, according to Zeng (2015), theoretically and quality management principles are considered incompatible with innovation. Quality management is the foundation for company sustainability and its application must be balanced with significant innovation (Li, Zhao, Zhang, Chung, \& Cao, 2018).

Companies tend to be followers of other companies rather than become leaders in conducting an innovation to avoid risk and reduce costs by limiting opportunities to invest in innovation (Hung, Chung, Peng, Hackley, Tiwsakul, \& Chou, 2011). As the result, the company must balance the quality and innovation as well as qualified management to prevent the company from damaging the environment. The company's decision to innovate still has to prioritize quality which also concerns to the environment aspects so that environmental performance will be achieved. According to Jackson, GopalakrishnaRemani, Mishra, and Napier (2016), Total Quality Management is designed to encourage continuous improvement in products and processes and to improve the ability of employees to support quality management-based innovation activities. Specific elements of Total Quality Management will support quality improvement through management support, employee development, and employee involvement in making quality management decisions to improve innovation and achieve environmental awareness for the company.

Awareness to maintain product quality and reduce the environmental impact as well as continuing the innovation is also carried out by Kebon Indah batik craftsmen. The batik craftsmen are members of the Kebon Indah Batik Association which is located in Kebon Village, Bayat, Klaten, Central Java. Kebon village is one of the centers of written batik 
using natural dyes. Before the DIY and Central Java earthquake disaster in 2006, batik craftsmen in this village became batik workers in batik businesses that already popular in capital cities. After the disaster, most of them returned to the village and only paint batik if there is an order from entrepreneurs in capital cities. Kebon Indah Batik Association was established in February 2009 (Desa Kebon. Blogspot.co.id/2011/03/village-kebonproducing-batik-friendly.html). Since June 2018 , the association has generated a turnover of up to 40 billion. They also actively establish communication with various agencies so that they often get facilities to attend national scale exhibitions. Moreover, the core management had been invited by the local embassy of Milan, Italy and America to share knowledge about natural color batik ranging from the production process to its marketing.

Based on the description, the researcher interested in conducting research on the effect of knowledge transfer and quality management on the environmental performance through innovations made by batik craftsmen who are members of the Kebon Indah Batik Association. This study aimed at determining the effect of knowledge transfer and quality management on environmental performance through innovation.

Several studies connected to the effects of knowledge transfer on performance through innovation (Xie, 2016; Hamdoun, Jabbour, \& Othman 2018; and Zheng, 2017). In the research of Ibarra et al (2018), it was shown that the level of public knowledge on industry development 4.0 influenced the business model in identifying business model innovations and their impact on performance. The research stated that it was necessary to improve quality management and innovation (Hung et al, 2011), Jackson et al (2016), and Hamdoun et al (2018). So this research wanted to know the effect of knowledge transfer and quality management on environmental performance through innovation in the Kebon Indah Batik Association, Bayat, Klaten, Central Java.

\section{Literature Review and Hypotheses Development}

According to Shaw and William (2009), innovation is a key element of the knowledge idea transfer. Knowledge is an important strategic resource for innovation activities (Xie, 2016), as a result of effective knowledge management which is considered as an important method for increasing a company's innovation capacity (Donate, 2015). Innovation system theory emphasizes the importance of knowledge in general and the transfer of knowledge among parties involved in particular innovation systems in. It means that the transmission and absorption of knowledge explicitly is an important aspect of innovation (Wehn \& Montalvo, 2018). Knowledge transfer activities enable the organizational members to share, disseminate, and replicate information (Donate, 2015). Therefore, a company's ability to change and exploit knowledge can determine the level of innovation, through the application of new methods to solve new problems and meet market demand (Joiner, 2006). Chung et al. (2009) argued that companies need to transfer and share it in purpose of gaining knowledge to be more innovative. According to Moorman and Miner (1998), innovation process involves the acquisition, dissemination and dissemination of new or existing knowledge. Knowledge transfer and its application are key factors for new product development (Kazanjian et al, 2000). 
Several empirical studies have shown that quality management is positively related to innovation (Abrunhosa \& Moura E Sá , 2008). However, the relationship between quality management and innovation is not always positive. For Zeng (2015), the philosophy and principles of quality management are considered incompatible with innovation. Specifically, the quality management process aims at eliminating all waste and inefficiency, and thus can damage innovation (Sadikoglu \& Zehir, 2010). Quality management can reduce surplus resources that can actually enrich innovation (Sadikoglu \& Zehir, 2010). Li et al. (2018) argue that quality management is the foundation for a company's contribution to sustainable development, and that its application in companies is usually associated with considerable innovation.

Some researchers also show the positive impact of quality management on innovation. Companies that adopt quality management in their system and culture show that the company has prepared an optimal environment for innovation (Pekovic and Galia, 2009). Based on research on 373 ISO certified Turkish companies, Sadikoglu and Zehir, (2010) found a positive relationship between total quality management practices (TQM) and innovation performance. These authors illustrate the importance of continuing efforts to implement TQM practices, exploring their positive effects on innovation performance. Regarding international standards, ISO 9001 standards promote process innovation more than product innovation (Manders, 2012). Ribiere et al, (2004) concluded that ISO 9001 certification can inhibit the performance of product innovation, while also facilitating the performance of process innovations through formalization of structures, cooperation and communication between functional areas. Based on previous researchs that has been conducted, the researcher proposes the following hypothesis:

H1 : Knowledge transfer has a positive and significant effect on innovation

H2 : Quality management has a positive and significant effect on innovation

At present the problem of environmental performance has become increasingly widespread, even it can prevent the transfer of knowledge among company members. As a result, companies must implement an environmental management system to reduce ambiguity and uncertainty in environmental performance by transferring knowledge. Claver et al. (2007) emphasize that the application of environmental management practices can lead to the emergence of new knowledge in environmental laws and human resources, at the operational level and can directly improve its performance.

Some researchers note a strong relationship between quality management and knowledge transfer (eg Dombrowski et al, 2017). According to Zheng (2015), quality management and innovation can increase employee empowerment, and the transfer of knowledge among employees influences environmental performance. It is not only influenced by aspects of innovation but the need for quality management to improve competitiveness and create competitive advantage (Manders, 2012). Therefore, researchers propose the following hypothesis: 
H3 : Knowledge transfer has a positive and significant effect on environmental performance.

H4 : Quality management has a positive and significant effect on environmental performance.

: Innovation has a positive and significant effect on environmental performance.

\section{Research Method}

This research used primary and secondary data. Primary data were collected by directly giving questionnaires to the employees of the Kebon Indah Batik Association in Bayat, Klaten, Central Java. The secondary data was obtained indirectly through intermediary media to collect the required supporting documents both those which was published directly by Association and documents issued by other parties. The population in this study is all groups in the Association which consisted of Sidoluhur, Nusa Indah, Nuju Makmur, Sido Makmur, and Tsp Mukti. The total population is 169 women who work in the natural dyes batik craft sector, so that it will be used as a whole in this study with census data collection techniques. The respondents who could not be met up in a long time were ignored. Therefore, the amount of data obtained was less than 169, not because of deliberate sampling but rather to the actual situation. The number of respondents who met the qualifications to be sampled was 169 . Dealing with the questionnaire in this study, researchers prepared alternative answers for the research subjects (respondents) according to the circumstances experienced and felt. For the alternative answers provided, researchers used a model developed by Likert with 6 scale intervals. In general, the Likert scale uses 5 scales but to avoid floating answers as intentional elements, the researcher modified it into 6 scales with categories of strongly disagree (1), disagree (2), somewhat disagree (3), somewhat agree (4), agree (5), and strongly agree (6). The statistical technique used to analyze data was Path Analysis by using SPSS software.

\section{Result and Discussion}

Validity test results based on calculations can be seen in the following table 1. Based on the table 1 , the calculated values of all questionnaire items including the research variables namely knowledge transfer, quality management, business innovation, and environmental performance, show probability values of (sig) $<0.05$. Therefore, the questionnaire from the research variables was all valid. The Cronbach Alpha value was obtained from all the resultsm, including the research variables which is greater than the value of 0.6 and it means reliable.

Next, a descriptive statistical analysis was conducted to explain the data description of the variables of knowledge transfer, quality management, business innovation, and 
environmental performance, consisted of several items of statement with a scale of Very Low, Low, Somewhat Low, Somewhat High, High and Very High. The following description of the respondents' assessment of each item of the research variable which was obtained by calculating the interval can be seen as follows:

1. Intervals $>1,000$ to $1,833 \rightarrow$ Very Low category

2. Intervals $>1,833$ to $2,667 \rightarrow$ Low category

3. Intervals $>2,667$ to $3,500 \rightarrow$ Somewhat Low categories

4. Intervals $>3,500$ to $4,333 \rightarrow$ High-Fair category

5. Intervals $>4,333$ to $5,167 \rightarrow$ High category

6. Intervals $>5,167$ to $6,000 \rightarrow$ Very High category

Table 1 Validity and Reliability Test Results

\begin{tabular}{|c|c|c|c|c|c|}
\hline Variable & Indicator & $\begin{array}{l}\text { Pearson } \\
\text { Correlation }\end{array}$ & Significance* & Conclusion & $\begin{array}{c}\text { Cronbach's } \\
\text { Alpha }\end{array}$ \\
\hline \multirow{5}{*}{$\begin{array}{l}\text { Knowlegde } \\
\text { Transfer }\end{array}$} & Item 1 & 0.893 & 0.000 & Valid & \multirow[t]{5}{*}{0.907} \\
\hline & Item 2 & 0.894 & 0.000 & Valid & \\
\hline & Item 3 & 0.859 & 0.000 & Valid & \\
\hline & Item 4 & 0.923 & 0.000 & Valid & \\
\hline & Item 5 & 0.795 & 0.000 & Valid & \\
\hline \multirow{5}{*}{$\begin{array}{c}\text { Quality } \\
\text { Management }\end{array}$} & Item 1 & 0.864 & 0.000 & Valid & \multirow[t]{5}{*}{0.924} \\
\hline & Item 2 & 0.876 & 0.000 & Valid & \\
\hline & Item 3 & 0.839 & 0.000 & Valid & \\
\hline & Item 4 & 0.902 & 0.000 & Valid & \\
\hline & Item 5 & 0.900 & 0.000 & Valid & \\
\hline \multirow[t]{5}{*}{ Inovation } & Item 1 & 0.916 & 0.000 & Valid & \multirow[t]{5}{*}{0.957} \\
\hline & Item 2 & 0.918 & 0.000 & Valid & \\
\hline & Item 3 & 0.945 & 0.000 & Valid & \\
\hline & Item 4 & 0.915 & 0.000 & Valid & \\
\hline & Item 5 & 0.930 & 0.000 & Valid & \\
\hline \multirow{6}{*}{$\begin{array}{l}\text { Environmental } \\
\text { Performance }\end{array}$} & Item 1 & 0.787 & 0.000 & Valid & \multirow[t]{6}{*}{0.924} \\
\hline & Item 2 & 0.883 & 0.000 & Valid & \\
\hline & Item 3 & 0.932 & 0.000 & Valid & \\
\hline & Item 4 & 0.929 & 0.000 & Valid & \\
\hline & Item 5 & 0.924 & 0.000 & Valid & \\
\hline & Item 6 & 0.909 & 0.000 & Valid & \\
\hline
\end{tabular}

Table 2 Descriptive Statistic

\begin{tabular}{llcc}
\hline NO & \multicolumn{1}{c}{ VARIABEL } & MEAN & CATEGORY \\
\hline 1 & Knowlegde Transfer & 4.58 & Good \\
2 & Quality Management & 4.60 & Good \\
3 & Inovation & 4.54 & Good \\
5 & Environmental Performance & 4.65 & Good \\
\hline
\end{tabular}


Table 3 Hypothesis Testing Results

\begin{tabular}{|c|c|c|c|c|c|}
\hline & & $\begin{array}{c}\text { Standardized } \\
\text { Coefficients }\end{array}$ & $\mathrm{t}$ & Sig. & Test Resuli \\
\hline \multicolumn{6}{|c|}{ First Equation: $Z Y_{1}=\gamma_{1.1} X_{1}+\gamma_{1.2} X_{2}+\varepsilon_{1}$} \\
\hline $\begin{array}{l}\text { Knowlegde } \\
\text { Transfer }\end{array}$ & Inovation & 0.600 & 7.474 & 0.000 & Significant \\
\hline $\begin{array}{l}\text { Quality } \\
\text { Management }\end{array}$ & Inovation & 0.328 & 4.094 & 0.000 & Significant \\
\hline \multicolumn{6}{|c|}{ Second Equation : $Z Y_{2}=\gamma_{2.1} Y_{1}+\gamma_{2.2} X_{1}+\gamma_{2.3} X_{2}+\varepsilon_{2}$} \\
\hline $\begin{array}{l}\text { Knowlegde } \\
\text { Transfer }\end{array}$ & $\begin{array}{l}\text { Environtmental } \\
\text { Performance }\end{array}$ & 0.357 & 3.666 & 0.000 & Significant \\
\hline $\begin{array}{l}\text { Quality } \\
\text { Management }\end{array}$ & $\begin{array}{l}\text { Environtmental } \\
\text { Performance }\end{array}$ & 0.433 & 4.944 & 0.000 & Significant \\
\hline Inovation & $\begin{array}{l}\text { Environtmental } \\
\text { Performance }\end{array}$ & 0.141 & 2.659 & 0.039 & Significant \\
\hline
\end{tabular}

Based on descriptive statistics table 3, it can be seen that variables of knowledge transfer, quality management, business innovation and environmental performance obtain score in the range $>4.333$ to 5.167. It shows that the group's knowledge transfer process and the quality management system, the innovation, and the environmental-based performance achieved by the Batik Association were all good. The research hypothesizes were drawn by using multiple linear regression analysis and Path Analysis. Multiple linear regression analysis was used to determine the effect of knowledge transfer, quality management toward the environmental performance through business innovation as presented as follows table 3 .

The study uses statistical analysis, namely Path Analysis. This analysis is used to test the effect of intervening variables $\left(Y_{1}\right)$ where the use of regression analysis was used to estimate the causality relationship between variables (casual model). Before using path analysis, a relationship model between variables should be developed, which is in this case was called a path diagram. The path diagram is arranged based on the thinking framework which was developed from the theory used in research. The independent variables are Knowledge Transfer $\left(X_{1}\right)$, Quality Management $\left(X_{2}\right)$. Innovation $\left(Y_{1}\right)$ is the intervening variables. Environmental Performance $\left(Y_{2}\right)$ is the dependent variable. Based on the influence models table 3 , the whole trajectory of influence can be arranged as follows figure 1.

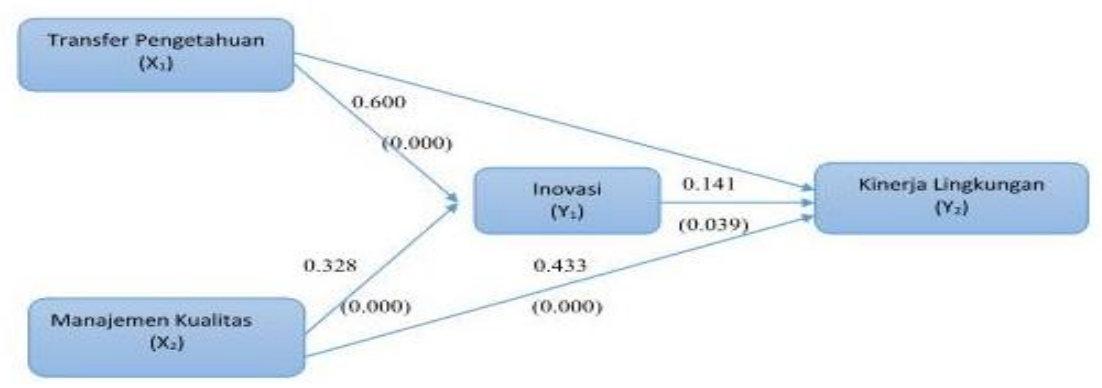

Figure 1 Results of Path Analysis Among X1, X2, Y1 and Y2

Source: Primary data processed, 2019 
Based on the Figure 1, it can be described that the direct and indirect effect of Knowledge Transfer (X1), Quality Management (X2) and Innovation (Y1) variable towards Environmental Performance (Y2).

\section{Effects of Knowledge Transfer on Environmental Performance through Innovation}

a. The direct effect of Knowledge Transfer (X1) on Environmental Performance (Y2) is 0.357 .

b. The indirect effect of Knowledge Transfer (X1) on Environmental Performance (Y2) through Innovation is $0.600 \times 0.141=0.084$

c. The total effect of Knowledge Transfer (X1) on Environmental Performance (Y2) through Innovation $=0.357+0.084=0.441$.

2. Effect of Quality Management on Environmental Performance through Innovation

a. The direct effect of Quality Management (X2) on Environmental Performance (Y2) is 0.433 .

b. The indirect effect of Quality Management (X2) on Environmental Performance (Y2) through Innovation is $0.328 \times 0.141=0.046$.

c. The total effect of Quality Management (X2) on Environmental Performance (Y2) through Innovation $=0.433+0.046=0.479$.

The analysis results show that knowledge transfer influences innovation and environmental performance. These results are consistent with previous research conducted by several researchers such as Claver et al., (2007) which states that the application of environmental awareness can lead to the emergence of new knowledge in environmental laws and human resources, at the operational level and can directly improve environmental performance. According to Shaw et al (2009), innovation is a key component of the knowledge transfer idea. Knowledge is an important strategic resource for innovation activities (Xie, 2016), as the results of effective knowledge management which is considered as an significant method for increasing a company's innovation capacity (Donate, 2015). Knowledge transfer activities enable organizational members to share, disseminate, and replicate information (Donate, 2015). Therefore, a company's ability to change and exploit knowledge can determine the level of innovation, through the application of new methods to solve new problems and meet market demand. Chung et al. (2009) argue that companies need to transfer and share them with the aim of gaining knowledge to be more innovative.

The results showed that quality management influences innovation and environmental performance. To create environmental performance is not only influenced by aspects of innovation but the need for quality management to improve competitiveness and create competitive advantage (Manders, 2016). Quality management can create an organizational environment to drive business innovation. However, the results of this study are not consistent with research conducted by Zeng (2015). According to Zeng (2015), philosophically and quality management principles are considered incompatible with innovation. Specifically, the quality management process aims at eliminating all 
production waste and inefficiency so that it can disrupt the role of innovation. According to Li et al (2018), quality management is the foundation for a company's contribution to sustainable development, and that its application in companies is usually associated with considerable innovation.

Some researchers also show the positive impact of quality management on innovation. Companies that adopt quality management in their system and culture show that they prepared an optimal environment for innovation (Pekovic and Galia, 2009). But the results of this study are not in accordance with research conducted by Sadikoglu and Zehir (2010). According to Sadikoglu and Zehir (2010), quality management can reduce the excess of available resources that can actually enrich innovation.

The results showed that innovation influences environmental performance. The relationship between knowledge management and innovation shows a complementary relationship between the two fields of management and provides a long-term competitive advantage in order to improve environmental performance. The key to success in implementing TQM lies in the role of human resources who create knowledge-based learning to win competition and improve environmental performance (Ribiere and Khorramshahgol, 2004). The results of this study are in accordance with research conducted by Zeng (2015). According to Zheng (2015), quality management and innovation promote employee empowerment, engagement and teamwork, all of which are strongly related to knowledge transfer by employees and affect environmental performance.

Based on the results of path analysis that there is an influence between Knowledge Transfer (X1) on Environmental Performance (Y2) through Innovation (Y1) and there is an influence between Quality Management (X2) on Environmental Performance (Y2) through Innovation (Y1). The results of this study are consistent with research conducted by Xie (2016), Wehn and Montalvo (2018), and Brachos et al (2007). Innovation bridges the role of knowledge transfer to environmental performance. Knowledge is an important strategic resource for innovation activities (Xie, 2016) which is the result of effective knowledge management. It is also considered as an important method for increasing the innovation capacity of a company (Donate, 2015). Referring to the innovation system theory, in which the importance of knowledge in general and the transfer of knowledge between parties involved in the innovation system, this means that the transfer and absorption of knowledge explicitly is an important aspect of innovation (When and Montalvo, 2018). When individuals are willing to transfer their knowledge, it can influence collective learning and synergistic benefits and develop creative and innovative ideas. Brachos et al (2007) say that when employees are motivated to share knowledge it will increase trust between employees in making contributions to improve innovation so that it becomes a key factor in achieving company success (Smith et al, 2005). Creating environmental performance is not only influenced by aspects of innovation but also need for quality management to improve competitiveness and create competitive advantage (Manders, 2012). 


\section{Conclusion}

Based on the results of the analysis and discussion, it can be concluded that knowledge and quality management have a positive effect on innovation and environmental performance in the Batik Kebon Indah Bayat Association of Klaten, Central Java. The current condition of global market competition has caught the attention of the public and the government to be more aware of the environmental and social effects for companies in order to increase the level of efficiency and minimize risks to human and the environment. The public should care about the impact caused by the company in producing a product, especially in environmental impacts. At present, the companies sometimes are more profit oriented and careless about the environmental impacts caused in the future.

The role of innovation is very important so that the survival of organizations and products can survive and can achieve competitive advantage. The merging of knowledge and quality management in innovating has been conducted by the Kebon Indah Batik Association in Bayat, Klaten, Central Java. The batik craftsmen are innovating by using natural dyes to reduce the environmental impact. Even the color is not inferior to artificial dyes available in the store. The contribution of the results of this study is expected to increase information about managing knowledge transfer and quality management in conducting business innovations on environmental performance to increase sales of batik using natural dyes, especially in the Kebon Indah Batik Association in Bayat, Klaten, Central Java.

\section{References}

Abrunhosa, A., \& Moura E Sá, P. (2008). Are TQM Principles Supporting Innovation in The Portuguese Footwear Industry?. Technovation, 28(4), 208-221.

https://doi.org/10.1016/j.technovation.2007.08.001

Alonso, L., Rubio, E. M., de Agustina, B., \& Domingo, R. (2017). Latest Clean Manufacturing Trends Applied to A Worldclass Manufacturing Management for Improving Logistics and Environmental Performance, Procedia Manufacturing, 13, 1151-1158. https://doi.org/10.1016/i.promfg.2017.09.177

Brachos, D., Kostopoulos, K., Soderquist, K. E. \& Prastacos, G. (2007). Knowledge Effectiveness, Social Context and Innovation, Journal of Knowledge Management, 11(5), 31-44. https:/ / doi.org/10.1108/13673270710819780

Chung, J.C., \& Jing, W. H. (2009). Strategic Human Resource Practices and Innovation Performance - The Mediating Role of Knowledge Management Capacity. Journal of Business Research, 62(1), 104-114. https://doi.org/10.1016/j.jbusres.2007.11.016

Claver, E., Lopez, M. D., Molina, J. F., \& Tar1, J. J. (2007). Environmental Management and Firm Performance: A Case Study. Journal of Environmental Management, 84(4), 606-619. https://doi.org/10.1016/i.jenvman.2006.09.012

Dombrowski, U., Richter, T., \& Krenkel P. (2017). Interdependencies of Industrie 4.0 \& Lean Production Systems: A use Cases Analysis. Procedia Manufacturing, 11, 1061-1068. https://doi.org/10.1016/i.promfg.2017.07.217 
Donate, M. J., \& de Pablo, J. S. (2015). The role of Knowledge-oriented Leadership in Knowledge Management Practices and Innovation. Journal of Business Research volume 68(2), 360-370. https://doi.org/10.1016/i.jbusres.2014.06.022

Hamdoun, M., Jabbour, C. J. C., \& Othman H. B. (2018), Knowledge Transfer and Organizational Innovation: Impacts of Quality and Environmental Management. Journal of Cleaner Production, 193, 759-770. https://doi.org/10.1016/j.jclepro.2018.05.031

Hung, K. P., Chung, A. H., Peng, N., Hackley, C., Tiwsakul, R. A., \& Chou, C.L. (2011). Antecedents of Luxury Brand Purchase Intention. Journal of Product \& Brand Management, 20(6), 457-467. https://doi.org/10.1108/10610421111166603

Ibarra D., Ganzarain J., \& Igartua J. I., (2018). Business Model Innovation Through Industry 4.0: A Review. Procedia Manufacturing, 22, 4-10. https://doi.org/10.1016/j.promfg.2018.03.002

Jackson, S. A., Gopalakrishna-Remani, V., Mishra, R., \& Napier, R. (2016). Examining the Impact of Design for Environment and the Mediating Effect of Quality Management Innovation on Firm Performance. International Journal of Production Economics, 173, 142152. https://doi.org/10.1016/j.ijpe.2015.12.009

Jing, Z., Chi, A.P., \& Yoshiki, M. (2015). The Impact of Hard and Soft Quality Management on Quality and Innovation Performance: An Empirical Study. International Journal of Production Economics, 162, 216-226. https://doi.org/10.1016/i.iipe.2014.07.006

Jing., Z., Wenqing, Z., Yoshiki, M., \& Xiande, Z. (2017). The Impact of Organizational Context on Hard and Soft Quality Management and Innovation Performance. International Journal of Production Economics, 185, 240-251. https://doi.org/10.1016/i.ijpe.2016.12.031

Joiner, T. A. (2007). Total Quality Management dan Performance: The Role of Organization Support and Co-Worker Support. International Journal of Quality \& Reliability Management, 24(6), 617-627. https://doi.org/10.1108/02656710710757808

Li, D., Zhao, Y., Zhang, L., Chung, X., \& Cao, C. (2018). Impact of Quality Management on Green Innovation. Journal of Cleaner Production, 170, 462-470. https://doi.org/10.1016/i.jclepro.2017.09.158

Manders, B. (2012). ISO 9000, Product Innovation and Business Performance. Doctoral dissertation. Rotterdam School of Management. Erasmus University

Moorman, C. \& Miner, A. S. (1998). Organizational Improvisation and Organizational Memory. Academy of Management Review. 23(4). https://doi.org/10.5465/amr.1998.1255634

Ribiere, V. M., \& Khorramshahgol, R. (2004). Integrating Total Quality Management and Knowledge Management. Industrial Marketing Management, 12, 113-123.

Sadikoglu, E., \& Zehir, C. (2010). Investigating the Effects of Innovation and Employee Performance on the Relationship between Total Quality Management Practices and Firm Performance: An Empirical Study of Turkish Firms. International Journal of Production Economics, 127(1), 13-26. https://doi.org/10.1016/j.ijpe.2010.02.013

Shaw, G., \& Williams, A. (2009), Knowledge Transfer and Management in Tourism Organisations: An Emerging Research Agenda. Tourism Management, 30(3), 325- 335. https://doi.org/10.1016/j.tourman.2008.02.023

Smith, K.G., Collins, C.J., \& Clark, K.D. (2005). Existing Knowledge, Knowledge Creation Capability, and the Rate of New Product Introduction in High-Technology Firms. The Academy of Management Journal, 48(2), 346-357. https://doi.org/10.5465/amj.2005.16928421 
Innovation of Business and Environmental Performance...

Wehn, U., Montalvo, C. (2018). Knowledge Transfer Dynamics and Innovation: Behaviour, Interactions and Aggregated Outcomes. Journal of Cleaner Production, 171, S56-S68. https://doi.org/10.1016/i.jclepro.2016.09.198

Xie, X., Fang, L., Jing, S., \& Huo, J. (2016). How does Knowledge Inertia Affect Firms Product Innovation?. Journal of Business Research, 69(5), 1615-1620.

https://doi.org/10.1016/i.jbusres.2015.10.027 